\title{
US - China trade war: reaction of stock exchanges to the transformation of the foreign policy agenda
}

\author{
Nadezhda S. Kuchma \\ National Research University "Higher School of Economics" \\ 11 Pokrovskii Blvd., Moscow, 109028, Russian Federation
}

\begin{abstract}
Over one and a half years, the attention of investors around the world has been focused on the confrontation of the two largest economies in the world. The aggravation of trade relations between the United States and China was one of the main reasons for the correction of world markets and the general risk aversion. The shifts and changes triggered by this conflict require more considerable attention since they bring about fundamental transformations of the landscape of international relations and the practice of economic interaction not only in relation to the parties to the conflict but also for the whole world, this conflict is not just a confrontation between the two strongest economies of the world, but also a turning point for updating the configuration of the world order.

This article aims to analyze the reactions of US and Chinese stock exchanges in connection with the unfolding of a trade conflict between the two countries and assess the level of adaptability of two economies to external challenges. The methodology of this study bases on the fundamentals of the general economic theory and the general theory of conflict resolution the research bases on the comparative method. The significant elements composing the scholars' analysis of political reality underlying the conflict is presented as well as stock exchanges' dynamic through the development of the confrontation.

The main conclusion of this study was that this conflict is not just a confrontation between the two strongest economies of the world, but also a turning point for updating the configuration of the world order.
\end{abstract}

Keywords: USA; China; tariff barriers; trade balance; investments; stock exchanges

\section{Introduction}

With the change of administration in the United States in 2017, everyone closely followed the development of communication between two active global players - the United States of America and the People's Republic of China. The reason for this close attention was the rhetoric of the new President Donald Trump, who throughout the entire election period spoke of the need to take action against the People's Republic of China: the politician accused China of a number of violations, including allegations of numerous thefts of American intellectual

(C) Kuchma N.S., 2019

(c) This work is licensed under a Creative Commons Attribution 4.0 International License https://creativecommons.org/licenses/by/4.0/ 
property, dumping of prices, protectionist policies in the domestic market of China. Starting from a positive context, the communication of the leaders of the two countries, Donald Trump and Chairman Xi Jinping, today represents not just an economic confrontation, but a clash of two sustainable economic models, one of which is the leader of the economic system of the whole world, and the other has the potential to become equal to it. This is the first large-scale economic confrontation between the United States and China for the first time in the history of US - China relations, the consequences of which are currently unpredictable due to a rapidly changing conjuncture.

\section{Literature review}

In connection with only recent actualization of the topic in the international space, studies on the proposed topic are few and often limited to comments by various experts and political scientists on local manifestations of the conflict. Nevertheless, there are a large number of studies describing the features of US Chinese communication before the period of economic confrontation and analyzing features of the development of the USA and China until 2017. The following texts became important for this study: "China and the Global Politics of Regionalization" by E. Kavalski, who explored the special role of China in the world arena and the significance of the paradigm of "new regionalism" for China's international activities; "China's Challenge to US Supremacy: Economic Superpower versus Rising Star"2 by John Glenn which reveals the peculiarities of the relationship between the two powers until 2016; and, the books of P. Navarro "Death by China: Confronting the Dragon - A Global Call to Action"3 and "The Coming China Wars. Where They Will Be Fought and How They Can Be Won"4 who is a current advisor of the US President on questions about commerce. The article "US - China Economic Confrontation: Ideology, Chronology, Meaning"5 by O. Vinogradov, A. Salitskiy and N. Semenova and "The USA - China: Trade War Unleashed" by O. Vinogradov and A. Salitskiy had a major impact on this study since these articles go beyond the standard methodologies for evaluating measures of international trade policy, and also offers an in-depth analysis of actions taking place on the world stage.

\footnotetext{
${ }^{1}$ Kavalski E. China, and the Global Politics of Regionalization (The International Political Economy of New Regionalisms). Routledge, 2009. 262 p.

${ }^{2}$ Glenn J. China's Challenge to US Supremacy: Economic Superpower versus Rising Star. Palgrave, 2016. 257 p.

${ }^{3}$ Navarro P., Autry G. Death by China: Confronting the Dragon - A Global Call to Action. Pearson FT Press, 2011. 320 p.

${ }^{4}$ Navarro P. The Coming China Wars: Where They Will Be Fought and How They Will Be Won. Pearson FT Press, 2006. 219 p.

${ }^{5}$ Vinogradov A.O., Salitsky A.I., Semenova N.K. US - China Economic Confrontation: Ideology, Chronology, Meaning // Vestnik RUDN. International Relations. 2019. Vol. 19. No. 1. Pp. 35-46.

${ }^{6}$ Vinogradov A.O., Salitsky A.I. The USA - China: Trade War Unleashed // Historical Perspectives Foundation "Perspectives". 2018, 13 August. http://www.perspektivy.info/oykumena/ ekdom/ssha_kitaj_torgovaja_vojna_razvazana_2018-08-13.htm (accessed: 09.05.2019).
} 


\section{Methodology}

The methodology of this study relies on the fundamentals of the general economic theory and the general theory of conflict resolution. The research bases on the comparative method. The significant elements composing the scholars' analysis of political reality underlying the conflict is presented as well as stock exchanges' dynamic through the development of the confrontation.

\section{Prerequisites of trade war between the US and China}

By the time Donald Trump was inaugurated as the forty-five president of the United States of America, the overall picture of trade with foreign partners was as it represents in Table.

Table

The volume of US trade with other countries in 2017, billion dollars

\begin{tabular}{lccc}
\hline \multicolumn{1}{c}{ State } & Export & Import & Trade balance \\
\hline China (PRC) & 130 & 505 & -376 \\
European Union (EU) & 283 & 435 & -151 \\
Mexico & 243 & 214 & -71 \\
Japan & 68 & 136 & -69 \\
Germany & 54 & 118 & -64 \\
The Republic of Korea & 48 & 71 & -23 \\
Canada & 282 & 299 & -17 \\
Total & $\mathbf{1 5 4 6}$ & $\mathbf{2 3 4 2}$ & $\mathbf{- 7 9 6}$ \\
\hline
\end{tabular}

Source: Top U.S. Trade Partners Ranked by 2017 U.S. Total Export Value for Goods (in millions of U.S. dollars). International Trade Administration. 13 July 2018.

The overall deficit in the trade balance shows that virtually all of the US industry has lost its competitiveness and has shifted to imported products. This thesis is also confirmed by the dynamics of the US trade balance: since 1976, the US trade balance was in short supply (imports exceeded exports in monetary terms), but from 2009 to 2017, the US trade deficit increased sharply from 500 billion to 796 billion dollars. $^{7}$ Such a relatively rapid transformation of the balance, above all, is a result of qualitative change in the approach of organizing industrial supply/production chains. However, a severe disadvantage of such a transformation is a reduction in the production capacity of a country, since it is often more expensive to produce locally than to produce something abroad.

As follows from Table, China was the leading partner for imports to the United States. At the same time, Chinese exports to the United States by 53\% consisted of vehicles (broadcasting equipment, computers, equipment parts) (Figure 1).

"At the same time, a particularly large negative balance of trade with China is of mixed origin: it is known that many Chinese enterprises with foreign participation are only an assembly platform where components and parts imported from East Asia acquire the final product form."

${ }^{7}$ Bureau of Economic Analysis. U.S. Department of Commerce. https://www.bea.gov/

${ }^{8}$ Vinogradov A.O., Salitsky A.I., Semenova N.K. US - China Economic Confrontation: Ideology, Chronology, Meaning // Vestnik RUDN. International Relations. 2019. Vol. 19. No. 1. Pp. 35-46. 


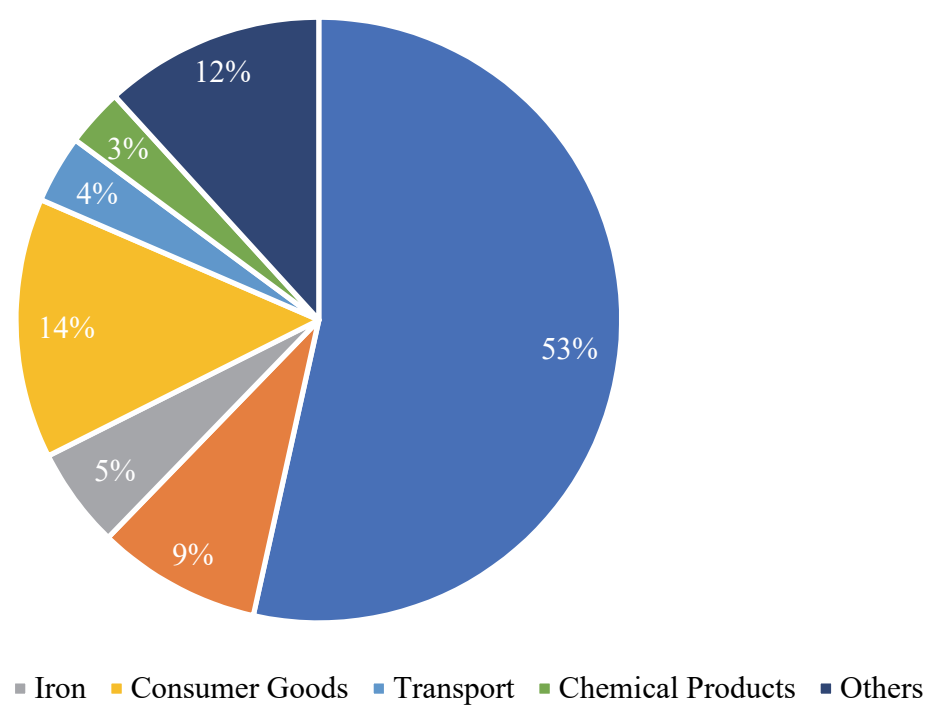

Figure1. What did the USA import from China in 2017?

Source: The Observatory of Economic Complexity, 2017.

An essential feature of the unfolding trade conflict between the United States and China was the transformation of the political landscape of the United States during the end of Barack Obama's presidential term and the election of a new president. Candidate for the presidency, Donald Trump, in preparation for the elections and primaries, as part of his political program and a potential US political course, actively demonstrated his most active attitude towards China. First of all, he appealed to the fact that China, by artificially lowering the yuan's rate ${ }^{9}$ (due to the undervalued yuan and export subsidies, Chinese goods were cheaper than competitors' goods - and this policy created many imbalances in the global economy, not only in the United States), actually dumped the prices of its goods, which, as a result, leads to "the destruction of American business and the reduction in the number of jobs." $"$ Moreover, as a decisive measure to counter the "Chinese currency manipulation," a $45 \%$ tax on Chinese goods to address the trade imbalance between the US and China. ${ }^{12}$ Another essential point for American rhetoric was the aspect of the protection of intellectual rights: "This includes stopping China's outrageous theft of intellectual property, along with their illegal product dumping, and their devastating currency manipulation. Our horrible trade agreements with China and many

${ }^{9}$ The yuan is not a freely convertible currency, and is de facto controlled by the Ministry of Finance of the PRC.

${ }^{10}$ Trump accuses China of 'raping' US with unfair trade policy // BBC News. 2016, 2 May. https://www.bbc.com/news/election-us-2016-36185012 (accessed: 12.02.2019).

${ }^{11}$ Ibid.

${ }^{12}$ Donald Trump favors high tariffs on Chinese exports // BBC News. 2016, 7 January. https://www.bbc.com/news/business-35258620 (accessed: 12.02.2019). 
others will be renegotiated." ${ }^{13}$ Besides, the presidential candidate has very harshly criticized the help of previous American leaders (especially the presidential candidate Hillary Clinton and her husband Bill Clinton) in assisting China in adhering to the WTO. ${ }^{14}$

The reason for this negative attitude towards one of the leading partners lies in the achievement of the Chinese economy and the Chinese ambitious around transformation of the world market which according to American economists "undermined the American economy." 15

\section{The logic of the trade war between the US and China}

23 March 2018 as part of the fight against the negative deficit in foreign trade, President Trump introduced new duties on the import of aluminum (10\%) and steel $(25 \%)$ for all countries supplying natural resources (with only a few partner countries deferred: Canada, Mexico, Brazil, Australia, EU countries, etc.). ${ }^{16}$ However, an essential part of the introduction of new duties is the fact that from 2003 to 2017, steel production in the USA decreased by $13 \%$ from 93.7 to 81.6 million tons (for comparison, in the largest producing country, China, the output grew six times to 832 million tons.), and aluminum production in the United States dropped by half: from 1.5 million tons (2003) to 740.9 thousand tons (2017) (China meanwhile increased production five times: from 6 million tons in 2003 to 31 million tons in 2016). ${ }^{17}$

Since China was the leading partner in exports to the US of aluminum $(13.2 \%)$ and steel $(3.6 \%)$, the measures taken had a rather painful effect on the Chinese industry. And, accordingly, the response measures were taken very quickly -1 April Beijing raised import tariffs to $25 \%$ on 128 items from the USA (including wine, fruits, vegetables, berries, meat) to which Washington responded with new duties on 1,313 items of imported products from China in the amount of about $\$ 45$ billion (Figure 2).

The measures taken by the United States seem to be quite understandable in the framework of the current agenda: it is essential to note that these categories have a direct connection with the strategy of the People's Republic of China on internal modernization "Made in China 2025". However, on the other hand, at the first stage of the confrontation of the United States and China, it can be said that the policy towards China was not favorable for the US economy - since the measures taken by the Chinese side hit the world financial market: as with the introduction of fees, the US stock index futures quotes, the E-Mini futures to

${ }^{13}$ Donald Trump 2016 RNC draft speech transcript // Politico. 2016. https://www.politico.com/ story/2016/07/full-transcript-donald-trump-nomination-acceptance-speech-at-rnc-225974 (accessed: 12.02.2019).

${ }^{14}$ Ibid.

${ }^{15}$ Navarro P. The coming China wars: Where they will be fought and how they will be won. FT Press, 2006. 219 p.

${ }^{16}$ Swanson A. Trump to Impose Sweeping Steel and Aluminum Tariffs // The New York Times. 2018, 1 March. https://www.nytimes.com/2018/03/01/business/trump-tariffs.html (accessed: 12.02.2019).

${ }^{17}$ Counted on data of World Steel in Figures 2003-2017. https://www.worldsteel.org/en/ dam/jcr:f9359dff-9546-4d6b-bed0-996201185b12/World+Steel+in+Figures.pdf (accessed 12.02.2019). 
Standard \& 500's index, the Dow Jones index futures and the NASDAQ 100 dropped quite sharply. ${ }^{18}$ The stock markets of China also experienced a fall: the main index of mainland China Shanghai Composite fell to $3.19 \%$, and the Hong Kong Hang Seng index lost $2.58 \% .{ }^{19}$ The reason for which was the change in macroeconomic indicators on the market and, as a result, there is a loss of profit, which is unacceptable for a business, as for the support of the economy.

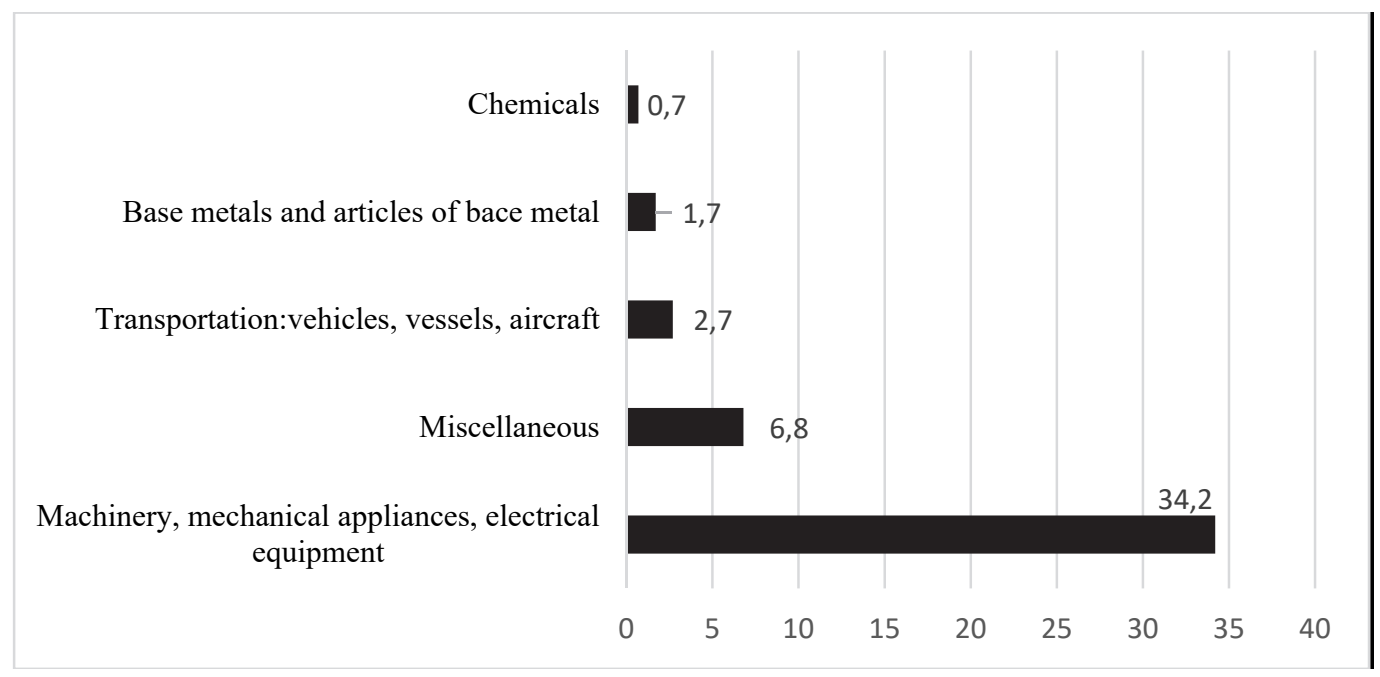

Figure 2. US imports subjects to Trumps proposed tariffs 2018 , $\$$ billion

Source: Notice of Determination and Request for Public Comment Concerning Proposed Determination of Action Pursuant to Section 301: China's Acts, Policies, and Practices Related to Technology Transfer, Intellectual Property, and Innovation. https://www.federalregister.gov/ documents/2018/04/06/2018-07119/notice-of-determination-and-request-for-public-commentconcerning-proposed-determination-of-action (accessed: 12.09.2018).

On May 18, 2018, negotiations were held in Washington on the possibilities of solving the trade conflict. As a result of the negotiations, the Chinese side indicated that the parties agreed not to start trade wars and refuse to increase duties on each other's goods. However, Washington did not mention the termination of the trade confrontation, stating that China promised to reduce the trade balance deficit between the countries by $\$ 200$ billion by the end of 2020 due to increased exports of goods/services, cancellation of tariffs and quotas for some goods (in mostly food). ${ }^{20}$ Elaboration of the conflict resolution tool kit the parties agreed to continue the discussion in the middle of June 2-17 at the next negotiations of trade delegations in Beijing. By the time of negotiations, the US President Donald

${ }^{18}$ Nasdaq falls for the fourth straight day and posts the worst start to September since $2008 / /$ CNBC. 2018, 7 September. https://www.cnbc.com/2018/09/07/us-markets-jobs-report-and-datain-focus.html (accessed 12.03.2019).

${ }^{19}$ Chinese markets' 2018 performance was their worst in a decade // CNBC. 2018, 31 December. https:/www.cnbc.com/2018/12/31/china-markets-2018-performance-was-worst-in-a-decade.html (accessed: 12.04.2019).

${ }^{20}$ US - China trade pact is taking shape, with tariff reductions on the table, official says. CNBC. 2018, 18 May. https://www.cnbc.com/2018/05/18/us-china-trade-deal-on-tariffs-takes-shapeunder-trump-administration.html (accessed: 12.04.2019). 
Trump expressed doubts about the success of the negotiations with China, publicly stating that it could not be successful "...because China has become very spoiled. The European Union has become very spoiled. Other countries have become very spoiled because they always got 100 percent of whatever they wanted from the United States." ${ }^{21}$ Such statements demonstrate a rather aggressive policy of reloading all relations not only with China but with the whole world, and to some extent reaffirming the leading position of the United States on the world stage. Furthermore, as part of the continuation of this idea, Donald Trump announced an increase in the rates of import customs duties on imports from China, but with some changes (with a reduction in the list from 1313 positions to 1102 ) $^{22}$ with the next words: "essential to preventing further unfair transfers of American technology and intellectual property to China, which will protect American jobs." 23

This triggered another drop in the above markets: the exchange of mutual threats between the PRC and the USA, the introduction of new restrictions, and an increase in duties undoubtedly sway the global economy, creating the effect of a funnel and dragging other players there. In such a situation, investors try to stay away from risky assets and prefer to transfer capital into protective tools. A clear proof of this is the parallel strengthening of the Swiss franc, the Japanese yen, as well as a decline in the yield of US Treasury bonds.

On July 6, 2018, "customs tariffs for 818 commodity items of US imports from China ( $\$ 34$ billion) increased by $25 \%$. Beijing responded with a mirror and an increase of $25 \%$ in customs duties on 545 US goods, including airplanes, automobiles, agricultural products (soybeans), fish and seafood, and chemical products (the cost was $\$ 34$ billion as in the case of the USA). ${ }^{24}$

September 24, US President Donald Trump announced the introduction of customs duties on goods from China in the amount of $10 \%$ with a total value of $\$ 200$ billion annually. Beijing was also warned that if he tried to respond to these duties, an additional package of trade restrictions for $\$ 267$ billion would be introduced against him. It should be noted that for American companies whose production was located in China, these duties would not apply. ${ }^{25}$

By the end of 2018, the situation slightly reduced the degree of tension the opportunity to change the current confrontation was possible thanks to the meeting of Xi Jinping and Donald Trump leaders on the margins of the G20 Summit. In general, the results of these negotiations can be called productive. Moreover, again, the subject of discussion was the question of postponing the introduction of duties, reducing the trade deficit by increasing exports from the US, this had

${ }^{21}$ US - China trade pact is taking shape, with tariff reductions on the table, official says. CNBC. 2018, 18 May. https://www.cnbc.com/2018/05/18/us-china-trade-deal-on-tariffs-takesshape-under-trump-administration.html (accessed: 12.04.2019).

${ }^{22}$ Trump puts $25 \%$ tariff on Chinese goods // BBC News. 2018, 15 July. https://www. bbc.com/news/business-44498484 (accessed 09/04/2019).

${ }^{23}$ Ibid.

${ }^{24}$ Vinogradov A.O., Salitsky A.I., Semenova N.K. US - China Economic Confrontation: Ideology, Chronology, Meaning // Vestnik RUDN. International Relations. 2019. Vol. 19. No. 1. Pp. 35-46.

${ }^{25}$ Ibid. 
a positive effect on all indices of the indices, which, although they did not return to their original positions, at least stopped falling.

Nevertheless, it is essential to note with what level of stock market falls both countries completed in 2018. Indeed, successful negotiations at the G20 summit reduced the level of anxiety on the stock exchanges of both countries (mainly because the US President agreed to postpone the introduction of new tariff restrictions on 10 and 25\% (worth $\$ 200$ billion) (Figures 3 and 4).

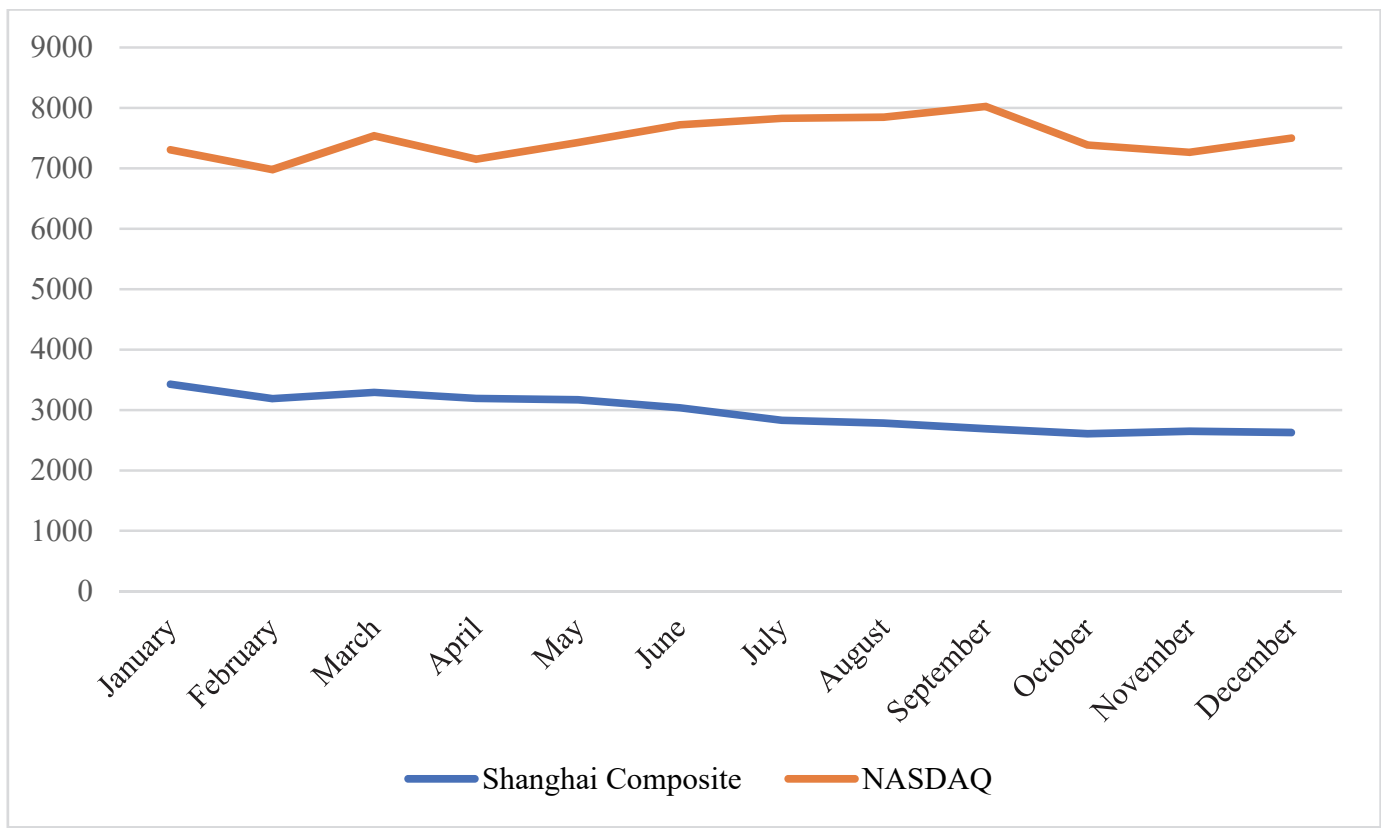

Figure 3. Dynamics of changes in SSI and NASDAQ in 2018

(values are taken every $14^{\text {th }}$ of each month at the time of the opening of the auction)

Source: The Nasdaq Stock Market https://www.nasdaq.com/ (accessed: 04.04.2019); Shanghai Stock Exchange. http://www.sse.com.cn/ (accessed: 04.04.2019).

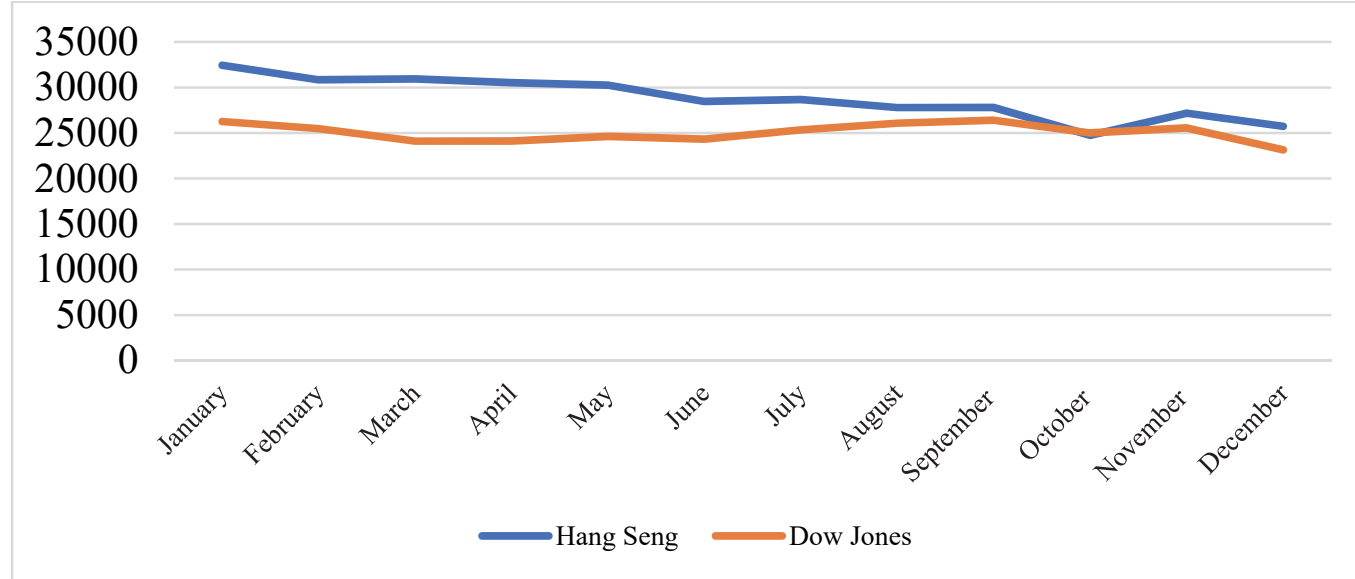

Figure 4. Dynamics of changes in SSI and NASDAQ in 2018

(values are taken every $30-31^{\text {st }}$ of each month at the time of the opening of the auction) 
According to Figures 3 and 4, the Chinese stock exchange for 2018 lost $24.6 \%$ of its rating due to trade sanctions imposed by the United States. "The stock market is often the barometer of a nation's economic health, and the weakness in China's A-share market reflects the serious troubles in the Chinese economy. ${ }^{26}$ This means that China was not ready for aggressive measures from the side of the foreign partner, and suffered a loss primarily in the industrial sector of investments, which by the end of the year had fallen by almost $2 \%$ of industrial profits. ${ }^{27}$

Along with this, there was a specific rise on the American stock exchange by the end of the year, because of the achievements at the summit and the delay in the introduction of a new package of tariff sanctions on China.

The United States issued an ultimatum to China, setting a deadline for concluding bilateral trade on March 2, 2019. Washington even threatened to raise duties on Chinese goods from 10 to $25 \%$ (which is in an agreement between the countries to make a deal within 90 days after the meeting at the summit in December). The United States issued an ultimatum to China, setting a deadline for concluding bilateral trade on March 2. Washington even threatened to raise duties on Chinese goods from 10 to $25 \%$ (which is in the agreement between the countries to make a deal within 90 days after the meeting at the summit in December). However, after a lot of meetings and consultations, Beijing ultimately abandoned all previously reached agreements and arrangements.

Assessing the situation entirely, it can be assumed that the reason for the refusal was that assurances did not support the US demands for the abolition of all customs sanctions against the United States that the US would not introduce new trade duties of 10 and $25 \%$, which the US President spoke about from December 2018. On May 5, the US president said that from May 10, tariffs would be increased according to the plan, since trade and economic negotiations with China "are moving very slowly." The increased US duties relate to the volume of Chinese goods at $\$ 250$ billion per year (about half of all imports from the PRC), while Beijing has a response duty for $\$ 110$ billion of imports of American goods (about $90 \%)^{28}$

May 10, 2019, in the stock markets of mainland China and Hong Kong, significant ups and downs occurred during the day, and they rose sharply in the afternoon after a sharp rise in the morning. Hong Kong's Hang Seng Index rose by almost $2 \%$ at the start of trading, and growth narrowed in the afternoon. The Shanghai Composite Index almost lost its morning increase after the opening of the af-

${ }^{26}$ Cit. Shanghai's stock index ends in 2018 as the world's biggest loser as trade war, slowing the Chinese economy weigh on confidence // South China Morning Post. 2018, 28 December. https://www.scmp.com/business/markets/article/2179765/hong-kong-shares-steady-early-tradingafter-wall-streets-wild (accessed 09.04.2019).

${ }^{27}$ Wang O. China's industrial profits drop for the first time in three years due to a trade war impact // China Morning Post. 2018, 21 December. https:/www.scmp.com/economy/china-economy/ article/2179652/chinas-industrial-profits-drop-first-time-three-years-due (accessed: 09.04.2019).

${ }^{28}$ Sino - US trade war: China announced that it would withstand the ups and downs of the Sino - Hong Kong stock market after the introduction of US tariffs // BBC News. 2019, 10 May. https://www.bbc.com/zhongwen/simp/chinese-news-48213174 (accessed: 10.05.2019). 
ternoon, but then it rebounded sharply and closed at 3.1\%. ${ }^{29}$ Major US stock indices fell by $0.3-0.5 \%$ amid aggravated trade relations with China. On Friday night, a duty rate of up to $25 \%$ on the import of some Chinese goods to the USA came into force. ${ }^{30}$

\section{Conclusion}

Despite the protectionist measures of the Trump administration, whose main goal was to reduce the trade deficit by imposing tariff restrictions, the US trade balance continues to deteriorate. The deficit in December 2018 increased by $1.7 \%$ and amounted to 54.6 billion US dollars. ${ }^{31}$ The problem is that the United States, because of its policy, needs to fill somehow the markets that were previously supplied with goods from China. Nevertheless, it is essential to note that strict protectionism against China has a severe impact on global business as a whole, however, China will suffer most from a trade war, many European companies have already begun to think about transferring production to other countries (Vietnam, India, etc.), so that due to high duties not to lose the American market (for example, Berkshire Brooks Runnings suspended the production of footwear in China, and now is in the process of transferring it to Vietnam precisely because of the imposed tariff restrictions). ${ }^{32}$ However, the fundamentally harsh position of the Trump administration concerning the PRC is not just an attempt to reduce the US trade deficit, but it also represents a coherent strategy for containing the Asian partner.

China's unwillingness to become dependent on the United States (meaning a rejection of the $\mathrm{G} 2$ project) provoked apparent concerns about its position as the United States: the United States, as the vanguard of the world economy, obviously does not want to accept the inclusion of new equal players. Particularly alarming was the internal transformation of China, starting with the "Made in China 2025" strategy, which will actually bring China to the same technological level with the countries of the European Union and the United States, ending with a proposal for a conceptually different economic cooperation system "Belt and Road Initiative", which challenges the classical methods of doing business in other countries. Improving the investment climate, improving and strengthening the le-

${ }^{29}$ US stock market disappointed with the US - China relationship // Stock Market Group. 2019, 10 May. http://stock-maks.com/fs/40255-fondovyy-rynok-ssha-razocharovan-otnosheniyamissha-i-kitaya.html (accessed: 10.05.2019).

30 Sino - US trade war: China announced that it would withstand the ups and downs of the Sino - Hong Kong stock market after the introduction of US tariffs // BBC News. 2019, 10 May. https:/www.bbc.com/zhongwen/simp/chinese-news-48213174 (accessed: 10.05.2019).

31 Scott R.B. Record U.S. trade deficit in 2018 reflects the failure of Trump's trade policies // Economic Policy Institute. 2019, 7 March. https://www.epi.org/blog/record-u-s-trade-deficit-in2018-reflects-failure-of-trumps-trade-policies/ (accessed: 10.05.2019).

32 Stempel J. CEO of Buffett-owned Brooks Running moves production out of China, cites tariff threat // The Reuters. 2019, 3 May. https://www.reuters.com/article/us-berkshire-buffett-brooks/ ceo-of-buffett-owned-brooks-running-moves-production-out-of-china-cites-tariff-threat-idUSKCN1S91DU (accessed: 10.05.2019).

Warren Buffett says the US - China trade war would be 'bad for the whole world' // The Reuters. 2019, 6 May. https://economictimes.indiatimes.com/markets/stocks/news/warrenbuffett-says-us-china-trade-war-would-be-bad-for-the-whole-world/articleshow/69205762.cms (accessed: 10.05.2019). 
gislative framework and in the aspects of protecting China's intellectual property with its high level of adaptability to changing external factors will ensure a high degree of competitiveness.

Nevertheless, the achievements of the Chinese economy were not enough to counter the policy pursued by the US: Paying attention to the dynamics of the American and Chinese indices, we can note the comparative stability of the NASDAQ and Dow Jones indices and the high sensitivity of the Chinese Hang Seng and Shanghai Composite. This indicates that despite the tough protectionism strategy in China, which is obviously negative for the US market, the US government uses domestic resources and tries to compensate for the loss of Chinese investment by reforming the financial system and providing large privileges for its companies, funds, etc. Thus, the US market remains reliable. As the practice of dealing with the consequences in China shows, China obviously shows a lower level of adaptability (for example, Shanghai Composite collapsed by $5.7 \%$ after Trump announced that the package of new tariff restrictions would begin on May 10,2019$)^{33}$.

Thus, the very nature of the political reality of the underlying war between the United States and the People's Republic of China lies in the very firm intention of the United States to prevent the PRC from increasing its influence on the United States and on the world stage at any cost (including risking its own business). At the moment, the United States has been able to demonstrate China's weaknesses to the world, reducing the level of confidence in its business environment (accusations of not respecting intellectual property rights and actual theft of technologies and developments from companies entering the Chinese market, protectionism of the PRC domestic market, dishonest tariffs and etc.) - Chinese stock indexes demonstrate this quite clearly. Nevertheless, a rise in US duties on Chinese goods and the continuation of the unfolding of the conflict may lead to a slowdown in the growth of the global economy, and also intensify the redistribution of global financial flows.

\section{References}

BBC News. (2016, 2 May). Trump accuses China of 'raping' US with unfair trade policy. https://www.bbc.com/news/election-us-2016-36185012 (accessed: 12.02.2019).

BBC News. (2016, 7 January). Donald Trump favours high tariffs on Chinese export. https:// www.bbc.com/news/business-35258620(Accessed: 12/02/2019)

BBC News. (2018, 15 July). Trump puts 25\% tariff on Chinese goods. https://www.bbc. com/news/business-44498484 (accessed: 09.04.2019).

BBC News. (2019, 10 May). Sino - US trade war: China announced that it will withstand the ups and downs of the Sino - Hong Kong stock market after the introduction of US tariffs. https://www.bbc.com/zhongwen/simp/chinese-news-48213174 (accessed: 10.05.2019).

CNBS. (2018, 18 May). US - China trade pact is taking shape, with tariff reductions on the table, official says. https://www.cnbc.com/2018/05/18/us-china-trade-deal-on-tariffstakes-shape-under-trump-administration.html (accessed: 12.04.2019).

${ }^{33}$ Nishizawa K., Wang C. Trump's Trade Tweets Hammer China's Stocks and Currency // The Bloomberg. 2019, 6 May. https://www.bloomberg.com/news/articles/2019-05-05/chinesestocks-may-come-under-pressure-at-reopen-after-holiday (accessed: 10.05.2019). 
CNBS. (2018, 7 September). Nasdaq falls for fourth straight day, posts worst start to September since 2008. https://www.cnbc.com/2018/09/07/us-markets-jobs-report-and-data-infocus.html (accessed: 12.03.2019).

Counted on data of World Steel in Figures 2003-2017. https://www.worldsteel.org/en/dam/ jcr:f9359dff-9546-4d6b-bed0-996201185b12/World+Steel+in+Figures.pdf (accessed: 12.02.2019).

Glenn J. (2016). China's Challenge to US Supremacy: Economic Superpower versus Rising Star. Palgrave.

Huan Xiang. (1981). On Sino - U.S. Relations. Foreign Affairs. https://www.foreignaffairs.com/ articles/china/1981-09-01/sino-us-relations (accessed: 28.03.2019).

Kavalski E. (2009). China and the global politics of regionalization. $1^{\text {st }}$ ed. Routledge.

Navarro P. (2006). The coming China wars: Where they will be fought and how they will be won. FT Press.

Navarro P., Autry G. (2011). Death by China: Confronting the Dragon - A Global Call to Action. Pearson FT Press.

Nishizawa K., Wang C. Trump's Trade Tweets Hammer China's Stocks and Currency. The Bloomberg. https://www.bloomberg.com/news/articles/2019-05-05/chinese-stocksmay-come-under-pressure-at-reopen-after-holiday (accessed: 10.05.2019).

Pillsbury M. (2015). The Hundred Year Marathon: China's Secret Strategy to Replace America as the Global Superpower. New York: St. Martin Griffin.

Politico. (2016). Donald Trump 2016 RNC draft speech transcript. https://www.politico.com/ story/2016/07/full-transcript-donald-trump-nomination-acceptance-speech-at-rnc-225974 (accessed: 12.02.2019).

Scott R.B. Record U.S. trade deficit in 2018 reflects failure of Trump's trade policies. Economic Policy Institute. https://www.epi.org/blog/record-u-s-trade-deficit-in-2018-reflectsfailure-of-trumps-trade-policies/ (accessed: 10.05.2019).

South China Morning Post. (2018, 28 December). Shanghai's stock index ends 2018 as the world's biggest loser as trade war, slowing Chinese economy weigh on confidence. https:// www.scmp.com/business/markets/article/2179765/hong-kong-shares-steady-earlytrading-after-wall-streets-wild (accessed: 09.04.2019).

Stempel J. CEO of Buffett-owned Brooks Running moves production out of China, cites tariff threat. The Reuters. https://www.reuters.com/article/us-berkshire-buffett-brooks/ceoof-buffett-owned-brooks-running-moves-production-out-of-china-cites-tariff-threatidUSKCN1S91DU (accessed: 10.05.2019).

Stock Market Group. (2019, 10 May). US stock market disappointed with US - China relationship. http://stock-maks.com/fs/40255-fondovyy-rynok-ssha-razocharovan-otnosheniyamissha-i-kitaya.html (accessed: 10.05.2019).

Swanson A. (2018, 1 March). Trump to Impose Sweeping Steel and Aluminum Tariffs. The New York Times. https://www.nytimes.com/2018/03/01/business/trump-tariffs.html (accessed: 12.02.2019).

The Reuters. (2019, 6 May). Warren Buffett says US - China trade war would be 'bad for the whole world'. https://economictimes.indiatimes.com/markets/stocks/news/warren-buffettsays-us-china-trade-war-would-be-bad-for-the-wholeworld/articleshow/69205762.cms (accessed 10.05.2019).

Varfalovskaya R.A. (2018). Razvitiye vneshney torgovli Kitaya v usloviyakh globalizatsii i "torgovykh voyn" SSHA [The development of China's foreign trade in the context of globalization and "trade wars" of the USA]. The Far Eastern Affairs, 6, 85-91. (In Russ.)

Vinogradov A.O., Salitsky A.I., Semenova, N.K. (2019). Ekonomicheskoye protivostoyaniye SSHA i Kitaya: ideologiya, khronologiya, smysl [US - China Economic Confrontation: Ideology, Chronology, Meaning]. Vestnik RUDN. International Relations, 19(1), 35-46. http://dx.doi.org/10.22363/2313-0660-2019-19-1-35-46. (In Russ.)

Wang O. China's industrial profits drop for first time in three years due to trade war impact. China Morning Post. https://www.scmp.com/economy/china-economy/article/2179652/ chinas-industrial-profits-drop-first-time-three-years-due (accessed: 09.04.2019). 
Article history:

Received: 15.09 .2019

Revised: 30.09 .2019

Accepted: 12.10.2019

\title{
For citation:
}

Kuchma N.S. (2019). US - China trade war: reaction of stock exchanges to the transformation of the foreign policy agenda. RUDN Journal of Economics, 27(3), 415-428. http://dx.doi.org/10.22363/2313-2329-2019-27-3-415-428

\section{Bio note:}

Nadezhda S. Kuchma, master in Asian Studies, School of Asian Studies, National Research University "Higher School of Economics". E-mail: n.s.kuchma@gmail.com

Научная статья

\section{Торговая война между США и Китаем: реакция фондовых бирж на трансформацию внешнеполитической повестки}

\author{
Н.С. Кучма \\ Национальный исследовательский университет «Высшая школа экономики» \\ Российская Федеращия, 109028, Москва, Покровский бульвар, 11
}

В течение полутора лет внимание инвесторов во всем мире было сосредоточено на противостоянии двух крупнейших экономиках мира. Обострение торговых отношений между США и Китаем стало одной из главных причин серьезных изменений на мировых рынках. Изменения и сдвиги, спровоцированные данным конфликтом, требуют самого пристального внимания, поскольку их последствия очевидно приведут к фундаментальным преобразованиям ландшафта международных отношений и практики экономического взаимодействия не только в отношении сторон конфликта, но и всего мира. Цель данной статьи - проанализировать реакции фондовых бирж США и Китая в связи с разворачивающимся торговым конфликтом между двумя странами, а также оценить степень гибкости и адаптации двух экономик к внешним вызовам. Исследование основано на сравнительном методе. Представлены основные элементы, из которых состоит научный анализ политической реальности, лежащей в основе конфликта, а также динамика фондовых бирж в ходе развития конфронтации.

Ключевые слова: США; Китай; тарифные барьеры; торговый баланс; инвестиции; фондовые биржи

\section{История статьи:}

Дата поступления в редакцию: 15.09.2019

Дата проверки: 30.09.2019

Дата принятия к печати: 12.10.2019 


\section{Для цитирования:}

Kuchma N.S. US - China trade war: reaction of stock exchanges to the transformation of the foreign policy agenda (Торговая война между США и Китаем: реакция фондовых бирж на трансформацию внешнеполитической повестки) // Вестник Российского университета дружбы народов. Серия: Экономика. 2019. Т. 27. № 3. С. 415-428. http://dx.doi.org/10.22363/2313-2329-2019-27-3-415-428

\section{Сведения об авторе:}

Кучма Надежда Сергеевна, магистр востоковедения, Школа востоковедения, Национальный исследовательский университет «Высшая школа экономики». E-mail: n.s.kuchma@gmail.com 